Bangladesh J. Zool. 42(1): 11-17, 2014

\title{
STATUS OF VULNERABLE LEOPARD WHIP RAY (HIMANTURA UNDULATA) AT TWO LANDING CENTRES OF CHITTAGONG AND COX'S BAZAR, BANGLADESH
}

\author{
Bikram Jit Roy, Nripendra Kumar Singha, S.M. Hasan Ali, \\ Md. Gaziur Rahman and Md. Fokhrul Alam \\ Marine Fisheries Survey Management Unit, Agrabad, Chittagong, Bangladesh
}

\begin{abstract}
Landing of vulnerable ray species, Leopard whip ray, Himantura undulata (Bleeker, 1852) was recorded from two fish landing centers of Bangladesh Fisheris Development Corporation. The highest landing volume was recorded $0.420 \mathrm{mt}$ in March 2010 and the lowest $0.112 \mathrm{mt}$ in August 2011. Average highest and lowest landings were $52.5 \mathrm{~kg}$ and $2.88 \mathrm{~kg}$ in the months of November2012 and in March 2009 respectively. During 2009-2010 H. undulata contributed only 0.560 MT (0.33 \%) followed by 2010-2011, 2011-2012 and 20122013 period were 0.893 MT $(0.28 \%), 0.882 \mathrm{MT}(0.23 \%)$ and $0.434 \mathrm{MT}(0.12 \%)$ of the year wise total landing volume of sharks and rays respectively. Month wise maximum and minimum recorded numbers of landed $H$. undulata were 59 and 4 in the month of November, 2012 and July, 2009 respectively. The highest and lowest percentage contributions were $2.54 \%$ and $0.28 \%$ in July, 2009 and March, 2013 respectively.
\end{abstract}

Key words: Landing, whip ray, fish harbour BFDC

\section{INTRODUCTION}

The shark and rays fishery in Bangladesh is largely artisanal. They are harvested as target species mainly by modified gill net, hooks and lines with other commercially important species. Rays are captured only as by catch in hooks and lines and some times exploited by trammel net and set bag net (Roy et al. 2007). Only 80-100 numbers of mechanized boats are engaged in commercial fishing for sharks and rays at Cox's Bazar and Chittagong marine water at the east and western part of the Bay of Bengal in Bangladesh. A large numbers of small size juveniles or new born sharks and rays are caught by shrimp and fish trawlers, which were not recorded or reported due to small size and low market value and discarded mainly as a trash fish (Roy et al. 2007).

Rays are caught and sold at a reasonable price where rays appear predominantly in the shallower strata up to $50 \mathrm{~m}$ depth (NDA-Malaysia 2006). In Bangladesh rays are not homogeneously distributed over the whole oceanic area but mainly found in two fishing zones, one is near Elephant point and the other in the center of the Middle ground area (near Mohipur) Distribution by

*Author for correspondence: <litroy1964@yahoo.com>. 
depth strata rays 10-20m-899, 20-50m-71, 50-80m-08, 80-100m-2, Av.10100m-214 numbers (Lamboeuf 1987).

In Bangladesh, there are only a few small shark fisheries processing plants in the form of cottage industry operate mostly by fisher flocks due to the irregular supply of shark and ray species (Roy et al. 2007). Rays are mostly consumed as a fresh meat, although some are processed as salted fish or dried form for utilization. During 2011-12 the total marine fish production was 578,620 MT of which shark fishery contributed only $0.80 \%$ (4205 MT) (DoF 2011-2012).

The Leopard whip ray- Himantura undulata (Bleeker,1852) is a species of sting ray of the family Dasyatidae, found widely in the shallow waters near the shore, close to land than breaking waves. Found in Indo-pacific region from the Bay of Bengal towards Northern Australian sea. Absent from western Indian Ocean. The species attain $140 \mathrm{~cm}$ (disc width); size at birth is $20 \mathrm{~cm}$ DW (White et al. 2006) across and has a diamond-shaped disc with rounded corners and a projecting, pointed snout. Its tail is long and whip like without fin folds. Adults have a striking dorsal color pattern consisting of large, dark brown rings and reticulations declined by thin yellow lines, while juveniles have a pattern of large dark spots. Mating season occurs in the winter. Most rays are viviparous, bearing live young in "litters" of five to ten (White et al. 2006). The multi species coastal fisheries, at both artisanal and commercial levels, comprise of 56 species of sharks and rays (Day 1969) and Roy et al. (2011) recorded 35 species of sharks $\&$ rays (11 shark and 24 ray species) in the marine territory of Bay of Bengal.

Though $H$. undulata is a vulnerable species by the IUCN red list (IUCN 2009) and it's economically important for its meat and skin in the abroad and local market and presently it is exploited commercially. So the study was under taken to know the present status of this species in Bangladesh.

\section{MATERIAL AND METHODS}

The study was conducted from July, 2009 to June, 2013 in two shark and ray fish landing centers at BFDC Fish harbour, Cox's Bazar and Fishery ghat fish landing center, Chittagong. These sampling centers were selected in order to cover a wide range of the most landing centers, retail and whole sale markets, target and incidental catches of the species, from the Bay of Bengal of Bangladesh region. Month wise total landing data, total numbers were recorded both at landing stations and interview of boat owners of commercial fishing vessels. The data were collected in new-moon, full-moon, first quarter, last 
quarter and other days of the moon month from the landing centers. Sampling days were 8 in each month of the year.

\section{RESULTS AND DISCUSSION}

Species description and distribution: During July, 2009 to June, 2013 recorded total numbers of $H$. undulata were 158 and their total landing weight was $2.769 \mathrm{mt}$. from the selected these landing centers was found.. In this study recorded highest length and weight of Leopard whip ray were $110 \mathrm{~cm}(\mathrm{DW})$ and $55.0 \mathrm{~kg}$ respectively and just born small size of $H$. undulata was recorded in 22 $\mathrm{cm}$ (DW) and its weight was $170 \mathrm{gm}$; where mother's body weight was $0.132 \mathrm{~kg}$ and DW $110 \mathrm{~cm}$ in the month of March, 2010, which is nearly similar to the report on White et al. 2006. The very rare ray's species were $H$. undulata contributed $1.54 \%$ and $2.17 \%$, which found in the month of July, 2009 and March, 2010 respectively (Roy et al. 2011). The abundance of $H$. undulata was very rare in the sampling period and found only in 12 months out of 60 months of the study periods; contributed less than $3.0 \%$ of the total month wise catch of sharks and rays, which is related on report Roy et al. 2011. It was observe that, in immature stage of $H$. undulata was seen many black spot to the dorsal view of the whole body and in virtual side dark line present to the anterior lobe and in mature stage reticulate dark brown rings present in the dorsal side of the body (Fig. 2). Findings from the study period on external characters of $H$. undulata (Fig. 2) are related to the published report.

Total landing: In the year 2009-2010 total $172.266 \mathrm{mt}$ of sharks and rays were recorded, among them $H$. undulata contributed only $0.33 \%(0.560 \mathrm{mt})$. During 2010-11 total landing of $H$. undulata was recorded $0.893 \mathrm{mt}(0.28 \%)$, where landing volume of total sharks and rays was 314.367 mt. During 2011-12 $H$. undulata contributed $0.23 \%(0.882 \mathrm{mt})$ of the total landed $(382.670 \mathrm{mt})$ shark and ray species. During 2012-2013 total landing of sharks and rays was $362.406 \mathrm{mt}$, of which landing of $H$. undulata was $0.434 \mathrm{mt}$ or $0.12 \%$ (Table 1 ).

Total Numbers: Month wise total numbers of $H$. undulata were recorded. During July, 2009 to June, 2010, total 12 numbers were landed followed by 27, 45 and 74 numbers during 2010-11, 2011-12 and 2012-13 respectively (Table $1)$.

Percentage contribution: Month wise percentage contribution by weight of $H$. undulata was analyzed; during July, 2009 to June, 2010 percentage composition was 2.54 in the month of July, 2009 and 2.17 in March, 2010. In July, 2010 to June, 2011 period percentage contribution was 1.15 in November, 2010 followed by 0.91 and 1.80 were in the month of January, 2011 and May, 2011 respectively. During July, 2011 to June,2012 was $2.35 \%$ in the month of 
July,2011 followed by 0.63\%, 0.84\%, 1.76\% were in August,2011, April,2012 and May,2012 respectively. In July, 2012 to June, 2013 percentage contribution was $0.41,0.28$ and 0.59 in the month of November, 2012, March, 2013 and May, 2013 respectively in the month wise total landing of sharks and rays (Table1).

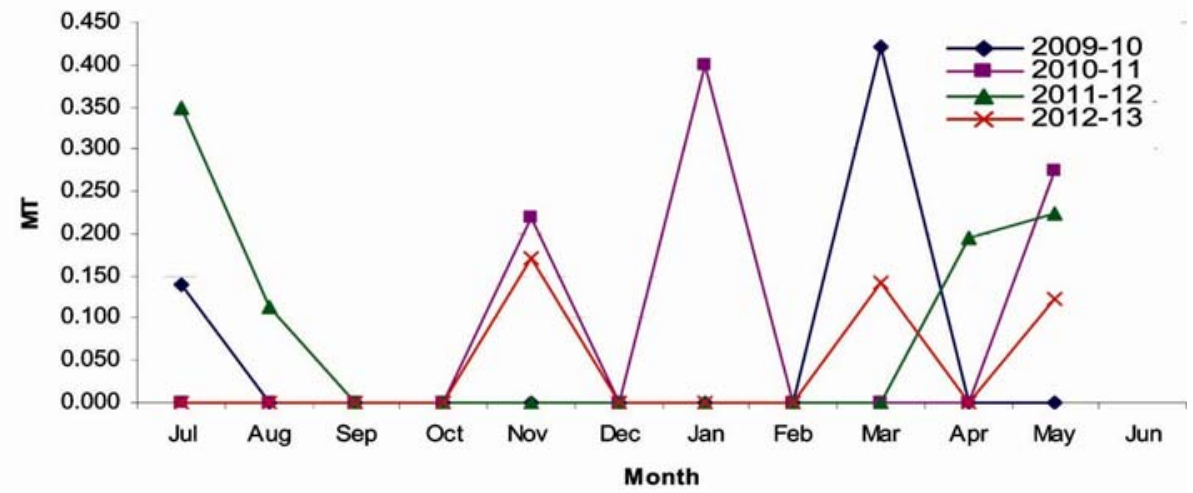

Fig. 1. Month and yearwise total landing (MT) of $H$. undulata.
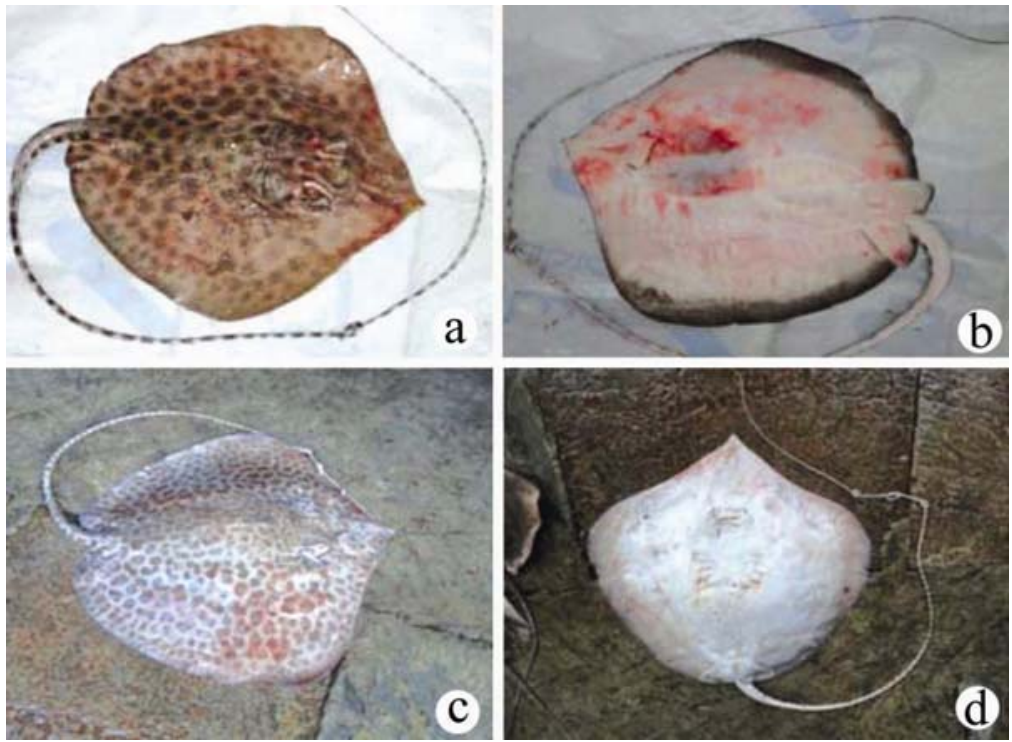

Plate 2. Immature and Mature stages of Himautura undulata. (a) Immature stage of H. undulata (Dorsal view), (b) Ventral view, (c) Mature stage of H. undulata (Dorsal view), (d) Ventral view.

Rays contributed approximately $1 \%(22,204.80$ tons $)$ in the total marine landing in India, most of them are sting ray. The following sting ray species are available in Parangipettai coast, Tamil Nadu, India -Dasatis sephen, D. 
imbricata, D. benneti, D. jenkensi, Himantura walga, $H$. uarnak, $H$. bleekeri, $H$. undulata, $H$. gerradi, Mobula diabolus, Aetabatus narinari, A. flagellum, but $H$. undulata are rare in position in the same coast (Rojesh et al. 2010), which is related this study report.

Table 1. Total landing, Percentage contribution and Total number of $\boldsymbol{H}$. undulata

\begin{tabular}{|c|c|c|c|c|c|c|c|c|}
\hline \multirow[t]{2}{*}{ Month } & \multicolumn{4}{|c|}{ July, 09 - June, 10} & \multicolumn{4}{|c|}{ July, 10 - June, 11} \\
\hline & TL (MT) & $\mathrm{HU}(\mathrm{MT})$ & $\%$ & $\mathrm{TN}$ & TL(MT) & HU(MT) & $\%$ & TN \\
\hline July & $172.266 \mathrm{MT}$ & 0.140 & 2.54 & 4 & 314.367 MT & - & - & - \\
\hline August & & - & - & - & & - & - & - \\
\hline September & & - & - & - & & - & - & - \\
\hline October & & - & - & - & & - & - & - \\
\hline November & & - & - & - & & 0.218 & 1.15 & 6 \\
\hline December & & - & - & - & & & & \\
\hline January & & - & - & - & & 0.400 & 0.91 & 8 \\
\hline February & & - & - & - & & - & - & - \\
\hline March & & 0.420 & 2.17 & 8 & & - & - & - \\
\hline April & & - & - & - & & - & - & - \\
\hline May & & - & - & - & & 0.275 & 1.80 & 13 \\
\hline June & & - & - & - & & - & - & - \\
\hline
\end{tabular}

Table contd (righ side).

\begin{tabular}{lllllllll}
\hline \multirow{2}{*}{ Month } & \multicolumn{3}{c}{ July, 11- June, 12 } & \multicolumn{5}{c}{ July, 12- June, 13 } \\
\cline { 2 - 9 } & TL (MT) & HU(MT) & $\%$ & TN & TL(MT) & HU(MT) & $\%$ & TN \\
\hline July & $382.670 \mathrm{MT}$ & 0.350 & 2.35 & 10 & $362.406 \mathrm{MT}$ & - & - & - \\
August & & 0.112 & 0.63 & 14 & & - & - & - \\
September & - & - & - & & - & - & - \\
October & - & - & - & & - & - & - \\
November & - & - & - & & 0.170 & 0.41 & 59 \\
December & - & - & - & - & - & - \\
January & - & - & - & - & - & - & - \\
February & - & - & - & & - & - & - & - \\
March & - & - & - & & - & - & - \\
April & 0.195 & 0.84 & 12 & & 0.123 & 0.59 & 10 \\
May & 0.225 & 1.76 & 9 & & - & - & - \\
June & - & - & - & & -
\end{tabular}

\# TL= Year wise Total landing of shark \& rays; $\mathrm{HU}=$ Total landing of $H$. undulata; $\mathrm{TN}=\mathrm{Total}$ number; $\%=$ Percentage contribution.

Utilization: Small sized of sharks and rays are used for producing fish meal and fertilizer if markets of human consumption are not available (Compagno, 1984). In Bangladesh, small sized and less weight of $H$. undulata used as dried form for human consumption, fish meal for fish culture pond and even used in poultry industry as feed (Compagno 1984). The flesh of $H$. undulata in the local market are consumed by non-Muslim people; tails are used locally as whip for decoration, bones as in village medicine and cosmetics industry and dorsal part 
of skin export as dried condition to China, Korea, Hong Kong, Singapore, UAE and Dubai to make bags, money bags and shoes.

It has been observed that, during 2009-2010 total landed numbers and average weight of $H$. undulata were 12 numbers $\& 46.66 \mathrm{~kg}$ in each followed by 27 and $33.07 \mathrm{~kg}, 45$ and $19.60 \mathrm{~kg}$ and 74 and $5.86 \mathrm{~kg}$ in the year 2010-11, 2011-12 and 2012-13, respectively. Thus the total number of $H$. undulata was gradually increased but average landing weight was gradually decreased. So it is clear that, in before exploitation of Leopard whip ray were large in size and weight, but now days is captured as small in size and weight. For the fishing pressure, it is now in vulnerable position stated at IUCN (2009) red data book.

\section{LITERATURE CITED}

ALONE, INTERNET, July, 2011, Shark catches data. Link, http//www.livescience.com/1027.shark salughter,and Global Shark Conservation.Link:http//www.PewEnvironment.org/sharksand http://en.wikipedia.org/wiki/Stingray.

BLEEKER, P. (1852). "Bijdrege tot de kennis der Plagiostomen van den Indischen Archipel". Verhandelingen van het Bataviaasch Genootschap van kunsten en Wetenschappen 24 (12): 1-92

COMPAGNO, L.J.V, 1984, FAO species catalogue, Vol.4: Shark of the world; Part 2 Carcharhiniformis. Food and Agriculture Organization of the United Nations, Rome, Italy. 655p.

DAY, F, 1969. The fishes of India Being a natural / history of the fishes known to in habit the Seas and Fresh water of India, Burma and Ceylon Vol-1, Text New Delhi, pp. 730-740.

DOF, 2011-2012, Fisheries Statistical Year Book of Bangladesh, Department of Fisheries, Matshya Bhaban, Dhaka, Bangladesh, 33 p.

IUCN, 2009. IUCN Red List of Threatened Species (ver. 2009.2). Available at: www.iucnredlist.org. (Accessed: 3 November 2009).

LAMBOEUF, M, 1987. Bangladesh Demersal Fish Resources of the continental shelf, R/V. Ansandhani Survey results, September, 1984-June, 1986. Food Agriculture Organization of the United Nations, Rome. 7 p.

NPA MALAYSIA. 2006, National Plan of Action for the Conservation and Management of Shark, Department of Fisheries. Ministry of Agriculture and Agro-Based Industry, Malaysia.

ROY, B.J, DEY, M. P, ALAM, M.F. and SINGHA, N.K., 2007. Present status of shark fishing in the Marine water Bangladesh, Presented in the Convention on the Conservation of Migratory Species (CMS)1st Meeting in Seychelles. December, 2007. Link: www.UNEP/CMS/MS/ Inf/ 10.4p.

ROY, B.J, ALAM, F.M, RHAMAN, G.M, SINGHA, N.K and AKHTAR, A, 2011. Landing trends, Species Composition and Percentage contribution of sharks and rays in Chittagong and Cox's Bazar, Bangladesh. Bangladesh Journal of Marine Sciences and Fisheries, Chittagong University, Chittagong, Bangladesh, Vol-2.

ROJESH, K.R, VENNILA, P. DAMOTHARAN, S. KANCHANA, M. ARUMUGAM and T. BALASUBRAMANIAN, 2010, CAS in Marine Biology, Faculty of Marine Science, Annamalai University, Parangipettai, Tamil Nadu, India. International Journal of recent Scientific Research URSR, October, 2010, Link at: http:// www. recentscientific.com 
WHITE, W.T, LAST, P.R., STEVENS, J.D, YEARSLEY, G.K. and FAHMI, D. 2006. Economically Important Sharks and Rays of Indonesia. Australian Centre for International. Agricultural Research, Canberra, Australia. pp. 238-239. ISBN 1-86320- 517-9

WILD FACT SHEETS HOME PAGE, 2013. Wild shores of Singapore, biog. Link at:file://C:/Document and setting/Administrator. MFSMU-2EE3947/ Desktop/Leopard.Com. Scientific report \& papers fol/Himantura undulata

(Manuscript received on 10 September, 2013; revised on 19 March, 2014) 